\title{
IMPLEMENTASI MODEL PROJECT BASED LEARNING PADA SISWA SD NEGERI 7 WONOGIRI
}

\author{
Sri Mulyati \\ Universitas Veteran Bangun Nusantara \\ E-mail; mulyatinuk.sri61@gmail.com
}

\begin{abstract}
This study aims to describe the improvement of learning outcomes in grouping building spaces using a project-based learning model for grade $1 A$ students at SD Negeri 7 Wonogiri semester 1.The subjects of this classroom action research were grade 1A SD students. Negeri 7 Wonogiri, totaling 29 students, consisting of 16 male students and 13 female students. The research was conducted in semester 1. Data collection about the quality of the learning process using observation instruments, and data about learning outcomes using learning outcome test instruments. The data analysis used an interactive descriptive analysis model. The research was conducted in two cycles, each cycle consisting of planning, action, observation and reflection stages. The results showed an increase in learning outcomes to recognize space using a project-based learning model for grade 1A students of SD Negeri 7 Wonogiri semester 1. This increase is shown by completeness in pre-cycle of $44.83 \%$, cycle 1 of $71.41 \%$, and cycle 2 of $89.66 \%$. The increase from pre-cycle, cycle 1 to cycle 2 was indicated by an increase in completeness from pre-cycle to cycle 1 with an increase of $13.8 \%$ and an increase in cycle 1 to cycle 2 amounting to $37.93 \%$.
\end{abstract}

Keywords; learning outcomes, building space, project based learning.

\section{PENDAHULUAN}

Pembelajaran di sekolah pada saat ini masih lebih terfokus pada hasil belajar berupa pengetahuan (knowledge) semata. Itupun sangat dangkal, hanya sampai pada tingkatan ingatan (C1) dan pemahaman (C2). Sementara itu, aspek keterampilan (psikomotor) dan sikap (attitude) juga banyak terabaikan. Mata pelajaran matematika di SD dipadukan dalam pembelajaran tematik pada pelaksanaan Kurikulum 2013 (Naziaha et al., 2020). Kurikulum 2013 dirancang untuk mengembangkan kompetensi siswa dalam ranah spiritual, sosial, pengetahuan, dan keterampilan. Salah satu materi matematika pada semester 1 tema 2 (kegemaranku) adalah Kompetensi Dasar 3.6 Mengenal bangun ruang dengan menggunakan berbagai benda konkret; dan Kompetensi Dasar 4.6 Mengelompokkan bangun ruang dengan menggunakan berbagai benda konkret. Kriteria Ketuntasan Minimal (KKM) yang ditetapkan adalah 75.

Hasil belajar matematika siswa kelas 1A SD Negeri 7 Wonogiri pada kondisi awal tergolong rendah. Pada kompetensi mengenal bangun ruang dengan menggunakan berbagai benda konkret (KD 3.6), dari 29 siswa, hanya 13 siswa (44,83\%) yang nilainya sudah tuntas atau mencapai Kriteria Ketuntasan Minimal (KKM) $(\geq 75,00)$, dan yang belum tuntas 16 siswa (55,17\%); sedangkan pada kompetensi mengelompokkan bangun ruang dengan menggunakan berbagai benda konkret (KD 4.6) siswa yang tuntas hanya sebanyak 11 siswa (37,93\%), dan 18 siswa $(62,07 \%)$ belum tuntas. 
Berdasarkan kondisi yang diuraikan di atas, maka penulis terdorong untuk mengadakan penelitian tindakan kelas dengan judul "Peningkatan Hasil Belajar Bangun Ruang dengan Penggunaan Model Project Based Learning pada Siswa Kelas 1A SDN 7 Semester 1“. Dengan penelitian ini diharapkan hasil belajar mengenal bangun ruang mencapai lebih dari $80 \%$ mencapai KKM. Selain itu, diharapkan siswa mampu mengelompokkan dan membuat bangun ruang secara mandiri dan kreatif.

Terlebih dahulu kita ketahui bahwa KKM tersebut merupakan cakupan dari ketuntasan hasil belajar siswa. Hasil belajar adalah hasil yang dicapai dari proses belajar mengajar sesuai dengan tujuan pendidikan. Hasil belajar diukur untuk mengetahui pencapaian tujuan pendidikan sehingga hasil belajar harus sesuai dngan tujuan pendidikan. Maka dapat diambil kesimpulan bahwa hasil belajar adalah perubahan tingkah laku baik pengetahuan, sikap dan keterampilan yang dicapai dalam bentuk angka-angka atau skor yang menjadi indikator kompetensi yang harus dikuasai siswa (Nugraha, A.S, Laksono, B, Anarsih, R \& Suswandari, 2019; Nugroho, Suyahman, Suswandari, 2020; Sobron Adi Nugraha, 2020;Purwanto, 2010).

Upaya untuk meningkatkan ketuntasan belajar maka proses pembelajaran sangat bergantung kepada model pembelajaran yang digunakan guru karena model pembelajaran memuat rencana yang akan guru lakukan di dalam kelas. Seiring dengan berjalannya waktu dan munculnya berbagai macam inovasi dalam dunia pendidikan maka banyak model-model pembelajaran yang lahir demi terwujudnya tujuan belajar yang baik (Ardayani, 2017; Napitupulu, 2019; Nazi, 2014).

Salah satu model pembelajaran yang dpat digunakan menuntaskan keberhasilan siswa adalah Project Based Learning. Berikut ini sintak Project Based Learning yang dikolaborasikan dalam pendekatan saintifik (Kemendikbud 2016:28).

Tabel 1. Hubungan Antara $5 \mathrm{M}$ dengan Sintaks pada Project Based Learning

\begin{tabular}{|l|l|}
\hline \multicolumn{1}{|c|}{ Kegiatan Pokok 5 M } & \multicolumn{1}{c|}{\begin{tabular}{c}
\multicolumn{1}{c|}{ Sintaks pada } \\
Pembelajaran Berbasis Proyek
\end{tabular}} \\
\hline Mengamati & Orientasi masalah \\
\hline Menanya & Penentuan pertanyaan mendasar \\
\hline Mengumpulkan Informasi & $\begin{array}{l}\text { Menyususn perencanaan dan jadwal, } \\
\text { melaksanakan dan memonitor proyek }\end{array}$ \\
\hline Mengasosiasi & Menguji hasil \\
\hline Mengomunikasikan & Mengevaluasi pengalaman \\
\hline
\end{tabular}

Menurut Thomas dkk dalam Wena (2014:145) pembelajaran berbasis proyek adalah sebuah model pembelajaran yang inovatif, dan lebih menekankan pada belajar kontekstual melalui kegiatan-kegiatan yang kompleks. Bound dan Felleti (dalam Hosnan 2014: 320) berpendapat model pembelajaran project based learningadalah "cara yang konstruktif dalam pembelajaran menggunakan permasalahan sebagai stimulus dan berfokus aktivitas pelajar". 
Definisi model pembelajaran project based learning dari beberapa tokoh tersebut dapat disimpulkan bahwa model pembelajaran project based learning adalah model pembelajaran yang menuntun siswa untuk bertindak aktif dan berpikir kritis untuk mampu memecahkan masalah atau menyelesaikan tugas yang berkaitan dengan masalah atau kehidupan nyata sehari-hari dan menciptakan suatu karya nyata yang berguna bagi diri sendiri atau orang lain sesuai tingkat usia atau kemampuan siswa.

Berdasarkan latar belakang di atas, maka tujuan penelitian ini adalah: untuk mendeskripsikan penerapan model Project Based Learning untuk meningkatkan hasil belajar mengenal bangun ruang pada siswa kelas 1A SD Negeri 7 Wonogiri semester 1.

\section{METODE PENELITIAN}

Penelitian ini adalah Penelitian Tindakan Kelas. Langkah-langkah pelaksanaanpenelitian tindakan kelas mengikuti Kurt Lewin (dalam Pardjono, 2007:21), dilakukan melalui empat tahap, yaitu perencanaan (planning), tindakan (acting), pengamatan (observasing), dan refleksi (reflecting).

Penelitian dilaksanakan di SD Negeri 7 Wonogiri Kabupaten Wonogiri pada siswa kelas IA semester 1. Subjek penelitian ini adalah siswa kelas IA SD Negeri 7 Wonogiri Semester 1 yang berjumlah 29 siswa yang terdiri dari 16 siswa laki-laki dan 13 siswa perempuan.

Data yang akurat dapat diperoleh dari pengumpulan data yang dilakukan dengan beberapa teknik yaitu: (1) melalui dokumen yaitu mengumpulkan data nilai hasil setiap siklus, (2) observasi yaitu mengumpulkan data berupa lembar observasi padasaat mengamati proses belajar siswa pada setiap siklus, (3) tes yang berupa tes tertulis pada aspek pengetahuan pada setiap siklus, (4) wawancara yang digunakan untuk mendapatkan data pendukung bagi guru, dapat dilakukan setelah pembelajaran berlangsung, dan (5) catatan lapangan merupakan gambaran umum yang digunakan sebagai keperluan penjelasan dan penafsiran, mencakup kesan dan penafsiran subjektif.

Penelitian tindakan kelas ini menggunakan trianggulasi sumber dan trianggulasi metode. Trianggulasi sumber data berasal dari guru kelas, siswa, dan hasil belajar siswa. Trianggulasi metode yaitu data dari pengumpulan dokumen, hasil observasi, dan hasil tes tertulis.Data yang dianalisis adalah nilai hasil tes kondisi awal dan nilai hasil tes setelah menggunakan pembelajaran model project based learning, dan dibandingkan dengan batas ketercapaian yang telah ditetapkan dalam indikator kinerja. 


\section{HASIL PENELITIAN}

\section{Deskripsi Prasiklus}

Berdasarkan hasil pengamatan pada kondisi awal, keaktifan siswa dalam mengikuti pembelajaran masih kurang baik. Proses pembelajaran berlangsung secara satu arah, guru aktif menjelaskan, siswa sangat pasif. Pengamatan dalam pembelajaran prasiklus mengenai antusiasme siswa dalam menjawab pertanyaan lisan dari guru, hanya beberapa siswa yang berani menjawab, kemungkinan karena siswa belum memahami apa yang disampaikan guru sehingga. Kerja sama dalam kelompok pada prasiklus menunjukkan siswa masih kurang baik. Guru hanya memberikan soal untuk dipecahkan secara berkelompok, akan tetapi terlihat yang mengerjakan hanya beberapa anggota.

Data menunjukkan keaktifan hanya 20,69\%, antusiasme 17,24\%, dan kerja sama 27,59\%, rata-rata 21,84\% (termasuk kategori kurang baik). Hasil belajar prasiklus pada KD 3.6. Mengenal bangun ruang dengan menggunakan benda konkret, siswa yang tuntas sebanyak 13 siswa (44,83\%), dan sebanyak 16 siswa $(55,17 \%)$ belum tuntas. Hal ini menunjukkan ketuntasan hasil belajar KD 3.6 termasuk kategori rendah. Sedangkan hasil belajar KD 4.6 Mengelompokkan bangun ruang dengan menggunakan berbagai benda konkret, hanya 9 siswa $(31,03 \%)$ yang sudah tuntas, dan sebanyak 20 siswa (68,97\%). Hal ini juga menunjukkan bahwa ketuntasan hasil belajar KD 4.6 termasuk kategori rendah.

\section{Deskripsi Siklus 1}

Pelaksanaan tindakan siklus 1 pada perencanaan sebagai berikut: mengindentifikasi masalah, membuat skenario pelaksanaan tindakan siklus yang terdiri dari 2 pertemuan, membuat skenario pelaksanaan tindakan yang berupa Rencana Pelaksanaan Pembelajaran (RPP), menyusun instrumen pelaksanaan tindakan, dan menyusun tes.

Pembelajaran siklus 1 dilaksanakan 2 kali pertemuan. Berikut ini merupakan hasil penelitian siklus 1: guru menggunakan model pembelajaran project based learning, keaktifan siswa dalam mengikuti pembelajaran sudah ada peningkatan dibandingkan dengan kondisi pembelajaran pada prasiklus. Siswa belajar secara berkelompok dengan diberikan tugas proyek membuat bangun ruang dari plastisin. Siswa merasa tertarik dan bersemangat mengikuti pembelajaran. Pada siklus 1 ini sebagian besar siswa aktif melaksanakan pembelajaran, akan tetapi masih ada beberapa siswa yang membuat plastisin menjadi bentukbentuk keinginannya sendiri, bukan berdasarkan tugas proyek dari guru.

Antusiasme siswa dalam menjawab pertanyaan lisan dari guru, sudah ada beberapa siswa yang menyampaikan jawaban, bahkan sudah berani memaparkan jawaban di depan kelas. Siswa juga memperhatikan ketika guru menyampaikan informasi. Pengamatan kerjasama dalam kelompok pada siklus 1 menunjukkan siswa mulai bisa bekerja sama dalam memecahkan masalah, mereka bekerja sama menyelesaikan proyek yang ditugaskan guru. 
Hasil belajar KD 3.6 Mengenal bangun ruang menggunakan berbagai benda konkret sudah ada peningkatan jika dibandingkan dengan hasil belajar pada prasiklus. Hasil belajar secara rinci dapat dilihat pada tabel di bawah ini.

Tabel 2. Data Nilai Hasil Belajar KD 3.6 Siklus 1

\begin{tabular}{|c|c|c|c|c|}
\hline No. & Interval & Kalsifikasi & Frekuensi & $\begin{array}{c}\text { Persentase } \\
\mathbf{( \% )}\end{array}$ \\
\hline 1. & $92<\mathrm{A} \leq 100$ & Sangat Baik & 7 & 24,13 \\
\hline 2. & $83<\mathrm{B} \leq 92$ & Baik & 8 & 27,59 \\
\hline 3. & $75 \leq \mathrm{C} \leq 83$ & Cukup & 6 & 20,69 \\
\hline 4. & $\mathrm{D}<75$ & Kurang & 8 & 27,59 \\
\hline Jumlah & & 29 & 100 \\
\hline \multicolumn{2}{|l|}{ Jumlah tuntas } & & 21 & 72,41 \\
\hline $\begin{array}{l}\text { Jumlah tidak } \\
\text { tuntas }\end{array}$ & & 8 & 27,59 \\
\hline
\end{tabular}

Tabel 2 menunjukkan hasil belajar KD 3.6 pada siklus 1 terdapat 7 siswa $(24,13 \%)$ mendapat predikat A (sangat baik), 8 siswa (27,59\%) mendapat predikat B(baik), 6 siswa $(20,69 \%)$ mendapat predikat C (cukup), dan 8 siswa (27,59\%) mendapat predikat D (kurang). Siswa yang tuntas sebanyak 21 siswa $(72,41 \%)$, dan yang belum tuntas sebanyak 8 siswa (27,59\%). Hal ini menunjukkan hasil belajar KD 3.6 termasuk kategori sedang.

Hasil belajar KD 4.6 sudah mengalami peningkatan dibandingkan dengan prasiklus. Data hasil belajar KD 4.6 secara rinci dapat dilihat pada di bawah ini.

Tabel 3. Data Nilai Hasil Belajar KD 4.6 Siklus 1

\begin{tabular}{|c|c|c|c|c|}
\hline No. & Interval & Kalsifikasi & Frekuensi & $\begin{array}{c}\text { Persentase } \\
(\mathbf{\% )}\end{array}$ \\
\hline 1. & $92<\mathrm{A} \leq 100$ & Sangat Baik & 2 & 6,90 \\
\hline 2. & $83<\mathrm{B} \leq 92$ & Baik & 6 & 20,69 \\
\hline 3. & $75 \leq \mathrm{C} \leq 83$ & Cukup & 5 & 17,24 \\
\hline 4. & $\mathrm{D}<75$ & Kurang & 16 & 55,17 \\
\hline \multicolumn{2}{|r|}{ Jumlah } & & 29 & 100 \\
\hline \multicolumn{2}{|r|}{ Jumlah tidak tuntas } & & 13 & 44,83 \\
\hline
\end{tabular}

Tabel 3 menunjukkan hasil belajar KD 4.6 pada siklus 1 terdapat 2 siswa $(6,90 \%)$ mendapat predikat A (sangat baik), 6 siswa (20,69\%) mendapat predikat B (baik), 5 siswa $(17,24 \%)$ mendapat predikat C (cukup), dan sebanyak 16 siswa $(55,17 \%)$ mendapat predikat D (kurang). Dengan demikian, siswa yang sudah tuntas sebanyak 13 siswa (44,83\%), dan belum tuntas sebanyak 16 siswa (55,17\%). Hal ini menunjukkan hasil belajar KD 4.6 termasuk kategori rendah.

\section{Deskripsi Siklus 2}

Pelaksanaan tindakan siklus 2 direncanakan sebagai berikut: mengindentifikasi masalah, membuat skenario pelaksanaan tindakan yang terdiri dari 2 pertemuan, membuat 
skenario pelaksanaan tindakan yang berupa Rencana Pelaksanaan Pembelajaran (RPP), menyusun instrumen pelaksanaan tindakan, dan menyusun tes.

Pembelajaran siklus 2 dilaksanakan 2 kali pertemuan.Hasil pengamatan dalam pembelajaran siklus 2, keaktifan siswa dalam mengikuti pembelajaran sudah menunjukkan hasil yang maksimal dibandingkan dengan pembelajaran prasiklus dan siklus 1 . Siswa belajar secara berkelompok dengan diberikan tugas proyek membuat bangun ruang dari barangbarang bekas seperti kardus, kaleng, balok kayu, dan bola plastik. Siswa merasa lebih tertarik dan bersemangat mengikuti pembelajaran. Beberapa siswa sudah tidak sabar untuk menyelesaikan tugas dari guru, karena siswa akan melakukan aktivitas mengecat barangbarang bekas tersebut. Pada siklus 2 ini hampir semua siswa aktif melaksanakan pembelajaran, semua terlibat langsung pada pembelajaran. Antusiasme siswa dalam menjawab pertanyaan juga meningkat. Sebagian besar siswa antusias dalam menjawab pertanyaan lisan dari guru, dan bersemangat dalam menyampaikan jawaban. Sementara itu, hasil belajar KD 3.6 pada siklus 2 menunjukkan adanya peningkatan. Hasil secara rinci dapat dilihat pada tabel di bawah ini.

Tabel 4. Data Nilai Hasil Belajar KD 3.6 Siklus 2

\begin{tabular}{|l|c|c|c|c|}
\hline No. & Interval & Kalsifikasi & Frekuensi & $\begin{array}{c}\text { Persentase } \\
(\%)\end{array}$ \\
\hline 1. & $92<\mathrm{A} \leq 100$ & Sangat Baik & 10 & 34,48 \\
\hline 2. & $83<\mathrm{B} \leq 92$ & Baik & 12 & 41,39 \\
\hline 3. & $75 \leq \mathrm{C} \leq 83$ & Cukup & 4 & 13,79 \\
\hline 4. & $\mathrm{D}<75$ & Kurang & 3 & 10,34 \\
\hline \multicolumn{2}{|l|}{ Jumlah } & & 29 & 100 \\
\hline \multicolumn{2}{|l|}{ Jumlah tuntas } & & 26 & 89,66 \\
\hline
\end{tabular}

Tabel 4 menunjukkan hasil belajar KD 3.6 pada siklus 2 terdapat 10 siswa $(34,48 \%)$ mendapat predikat A (sangat baik), 12 siswa mendapat predikat B(baik), 4 siswa (13,79\%) mendapat predikat C (cukup), dan sebanyak 3 siswa $(10,34 \%)$ mendapat predikat D (kurang).Pada akhir siklus 2, siswa yang tuntas sebanyak 26 siswa (89,66\%), dan siswa yang belum tuntas sebanyak 3 siswa (10,34\%). Hal ini menunjukkan hasil ketuntasan belajar KD 3.6 masuk dalam kategori tinggi. Sementara itu, hasil belajar siklus 2 untuk KD 4.6 juga meningkat. Hasil belajar KD 4.6 secara rinci dapat dilihat pada tabel berikut. 
Tabel 5. Data Nilai Hasil Belajar KD 4.6 Siklus 2

\begin{tabular}{|c|c|c|c|c|}
\hline No. & Interval & Kalsifikasi & Frekuensi & Persentase (\%) \\
\hline 1. & $92<\mathrm{A} \leq 100$ & Sangat Baik & 9 & 31,03 \\
\hline 2. & $83<\mathrm{B} \leq 92$ & Baik & 11 & 37,94 \\
\hline 3. & $75 \leq \mathrm{C} \leq 83$ & Cukup & 4 & 13,79 \\
\hline 4. & $\mathrm{D}<75$ & Kurang & 5 & 17,24 \\
\hline \multicolumn{2}{|l|}{ Jumlah } & & 29 & 100 \\
\hline \multicolumn{2}{|l|}{ Jumlah tuntas } & & 24 & 82,76 \\
\hline \multicolumn{2}{l}{ Jumlah tidak tuntas } & & 5 & 17,24 \\
\hline
\end{tabular}

Tabel 5 menunjukkan hasil belajar KD 4.6 pada siklus 2 terdapat 9 siswa (31,03\%) mendapat predikat A (sangat baik), 11 siswa mendapat predikat B (baik), 4 siswa (13,79\%) mendapat predikat C (cukup), dan sebanyak 5 siswa $(17,24 \%)$ mendapat predikat D (kurang). Dengan demikian, jumlah siswa yang tuntas sebanyak 24 siswa $(82,76 \%)$, dan sebanyak 5 siswa $(17,24 \%)$ belum tuntas. Hal ini menunjukkan ketuntasan hasil belajar KD 4.6 termasuk kategori tinggi.

Nilai hasil belajar siswa pada Prasiklus, Siklus 1, dan Siklus 2 dihimpun, dan diperoleh data hasil belajar KD 3.6 seperti pada tabel di bawah ini.

Tabel 6. Hasil Belajar KD 3.6 Prasiklus, Siklus 1, dan Siklus 2

\begin{tabular}{|c|c|c|c|c|}
\hline No. & Interval & Prasiklus & Siklus 1 & Siklus 2 \\
\hline 1. & $92<\mathrm{A} \leq 100$ & 1 & 7 & 10 \\
\hline 2. & $83<\mathrm{B} \leq 92$ & 6 & 8 & 12 \\
\hline 3. & $75 \leq \mathrm{C} \leq 83$ & 6 & 6 & 4 \\
\hline 4. & $\mathrm{D}<75$ & 16 & 8 & 3 \\
\hline & Ketuntasan & $44,83 \%$ & $71,41 \%$ & $89,66 \%$ \\
\hline
\end{tabular}

Tabel 6 di atas menunjukkan hasil belajar siswa pada KD 3.6 sudah meningkat dari prasiklus, siklus 1 sampai siklus 2. Peningkatan ini ditunjukkan dengan persentase ketuntasan pada prasiklus 44,83\%, siklus 171,41\%, dan pada siklus 2 menjadi 89,66\%. Hasil belajar KD 3.6 pada siklus 2 menunjukkan 26 siswa $(89,66 \%)$ sudah mencapai/di atas KKM $(\geq 75,00)$. Dengan demikian, ketuntasan siswa untuk KD 3.6 telah mencapai indikator kinerja yang ditentukan, yakni 24 siswa tuntas (82\%). Data hasil belajar pada Prasiklus, Siklus 1, dan Siklus 2 disajikan pada tabel di bawah ini. 
Tabel 7. Hasil Belajar KD 4.6 Prasiklus, Siklus 1, dan Siklus 2

\begin{tabular}{|c|c|c|c|c|}
\hline No. & Interval & Prasiklus & Siklus 1 & Siklus 2 \\
\hline 1. & $92<\mathrm{A} \leq 100$ & 0 & 2 & 9 \\
\hline 2. & $83<\mathrm{B} \leq 92$ & 3 & 6 & 11 \\
\hline 3. & $75 \leq \mathrm{C} \leq 83$ & 6 & 5 & 4 \\
\hline 4. & $\mathrm{D}<75$ & 20 & 16 & 5 \\
\hline \multicolumn{2}{|c|}{ Persentase ketuntasan } & $31,03 \%$ & $44,83 \%$ & $82,76 \%$ \\
\hline
\end{tabular}

Tabel 7 menunjukkan hasil belajar siswa untuk KD 4.6 menunjukkan peningkatan dari prasiklus, siklus 1 hingga siklus 2. Peningkatan ini ditunjukkan dengan persentase ketuntasan pada prasiklus ke siklus 1 dengan peningkatan 13,8\% (31,03\% - 44,83\%), dan peningkatan siklus 1 ke Siklus 2 sejumlah 37,93\% (44,83\% - 82,76\%). Dengan demikian, hasil belajar siswa untuk KD 4.6 sudah mencapai indikator kinerja penelitian maka penelitian ini dianggap berhasil dan diakhiri pada siklus 2 .

\section{KESIMPULAN}

Berdasarkan hasil penelitian dan pembahasan sebagaimana diuraikan di atas, hasil penelitian dapat disimpulkan bahwa terdapat peningkatan hasil belajar mengenal bangun ruang dengan menggunakan model project based learning pada siswa kelas 1A SD Negeri 7 Wonogiri semester 1. Peningkatan ini ditunjukkan dengan ketuntasan pada prasiklus sebesar $44,83 \%$, siklus 1 sebesar 71,41\%, dan siklus 2 sebesar 89,66\%. Peningkatan dari prasiklus, siklus 1 hingga siklus 2 ditunjukkan dengan peningkatan ketuntasan pada prasiklus ke siklus 1 dengan peningkatan 13, 8\% dan peningkatan siklus 1 ke Siklus 2 sejumlah 37,93\%. Dengan demikian, model project based learning menjadikan siswa lebih meningkatkan dalam hasil belajarnya khususnya dalam memahami bangun ruang. Hal ini dapat berdampak pada pembelajaran selanjutnya yang dapat diterapkan oleh guru agar senantiasa melakukan inovasi dan kreatifitas model pembelajaran dalam setiap proses pembelajaran di kelas.

\section{ACKNOWLEDGEMENT}

Terima kasih pada program studi PGSD FKIP Universitas Veteran Bangun Nusantara yang telah memberikan ijin dalam melaksanakan penelitian ini. Terima kasih juga peneliti ucapkan kepada Alfiah Dian Pratiwi, S.Pd.SD yang telah membantu terlaksananyanya proses dan akhir dari penelitian ini. 


\section{BIBLIOGRAFI}

Ardayani, L. (2017). Proses Pembelajaran Dalam Interaksi Edukatif. Itqan, 8(2), 187-200.

BSNP. 2006. Permendiknas RI No. 22 Tahun 2006 tentang Standar Isi untuk Satuan Pendidikan Dasar dan Menengah. Jakarta : Depdikbud

Dirjen Pendidikan Dasar dan Menengah Kemendikbud. 2016. Pedoman Penilaian untuk Sekolah Dasar. Jakarta: Kemendikbud

Kemendikbud. 2016. Permendikbud Nomor 23 Tahun 2016 tentangStandar Penilaian Pendididkan. Jakarta : Kemdikbud

Napitupulu, D. S. (2019). Proses Pembelajaran Melalui Interaksi Edukatif dalam Pendidikan Islam. Tazkiya, 8(1), 125-138.

Nazi, M. (2014). Pentingnya Interaksi Edukatif Pendidik (Guru) Dalam Upaya Pembentukan Akhlak Peserta Didik Di Sekolah S(tudy Mata Pelajaran Akidah Akhlak di Mts Miftahul Amal). 1-109.

Naziaha, S. T., Maula, L. H., \& Sutisnawati, A. (2020). Analisis Keaktifan Belajar Siswa Selama Pembelajaran Daring Pada Masa Covid-19 Di Sekolah Dasar. 7(2), 109-120.

Nugraha, A.S, Laksono, B, Anarsih, R \& Suswandari, M. (2019). Persepsi Siswa dalam Studi Pengaruh Daring Learning terhadap Minat Belajar IPA. Scaffolding, 1(2), 30-38.

Nugroho, Suyahman, Suswandari, M. (2020). Peranan Mata Pelajaran PPKn Dalam Rangka Menumbuhkan Nilai Karakter Religius Siswa Kelas IV Di SDN 3 Wuryorejo Kabupaten Wonogiri Tahun Pelajaran 2017/2018. Civics Education And Social Sciense Journal (CESSJ, 1(1), 18-36.

Sobron Adi Nugraha, T. S. \& M. S. (2020). Studi pengaruh daring learning terhadap hasil belajar matematika kelas IV. Jurnal Inovasi Pendidikan, 1(3).

Wena, Made. 2014. Strategi Pembelajaran Inovatif Kontemporer: Suatu Tinjauan Konseptual Operasional. Jakarta: Bumi Aksara. 